\title{
Final Move for an Integrated EU Energy Market: Energy Union*
}

\author{
Ayşegül Uçkun \\ KTO Karatay University, Konya, Turkey
}

\begin{abstract}
EU is in position of world's largest energy importer and plays an active role in energy markets. Therefore, the EU's energy policy has not only local but also global effects. Because of the two oil crises in the 1970's, energy has taken an important place in the EU's agenda and has become one of the EU's highest priorities as the part of the EU's goal of Single Market. Especially, the 1987 Single European Act followed by the goal of Single Market has come to dominate the idea of the necessity of having a single market for energy. A chapter about energy has been added into the letter of the 2009 Treaty of Lisbon for the first time, thus energy has gained a new dimension and has had a legal basis. However, although there are energy rules defined at European level, there are 28 national regulatory structures in practice. Therefore, an integrated energy market is needed to create more competition, to increase market efficiency through better use of energy generation facilities across the EU, to produce affordable prices for consumers, and to move as whole, not as 28 separate countries. In this regard, the idea of creation of the Energy Union has emerged and the European Commission has published a detailed action plan for the Energy Union on February 25, 2015. In this study, historical process of initiatives for the creation of common energy policy in the EU is analyzed and the future of Energy Union is discussed.
\end{abstract}

Keywords: European union, energy policy of the EU, energy union

\section{Introduction}

Having $12.5 \%$ of the world's energy consumption as of 2013, European Union provides $53 \%$ of the energy, it consumes from imported resources and is the biggest energy importer of the world. About $66 \%$ of the natural gas consumption, $90 \%$ of crude oil, and $42 \%$ of solid fuels are provided by importing. Therefore, the energy bill for EU is around 300 billion euros in 2013 and more than 300 billion euros are spent on crude oil and petroleum products, one third of this importation is made from Russia. Energy importation of EU constitutes about $23 \%$ of total importation (European Commission, 2014).

Due to being an important energy consumer, energy policy of EU has not only regional effects but also global effects. Therefore, the energy policy of EU being based on strong objectives becomes more of an issue. Energy prospect of EU generally makes an impression of dependence on foreign sources and this includes the issues of establishing security of energy supply, good operation of energy market, increasing utilization of new and renewable energy sources, and supporting interconnection of energy networks into priority objectives of EU.

\footnotetext{
* It was presented at EY International Congress on Economics II that was held on November 5-6, 2015 in Ankara/Turkey. Ayşegül Uçkun, research assistant, Department of Energy Management, Faculty of Business and Administrative Sciences, KTO Karatay University, Konya, Turkey.

Correspondence concerning this article should be addressed to Ayşegül Uçkun, KTO Karatay Universitesi Isletme ve Yonetim Bilimleri Fakültesi Akabe Mah, Alaaddin Kap Cad, No. 130 42020, Konya, Turkey.
} 
Energy policy of EU goes back to 1950's. Two of the communities, European Coal and Steel Community (ECSC), European Atomic Energy Community (EURATOM) and European Economic Community (EEC), which formed the EU, are exclusively about energy. Accordingly, EU energy policy started to be shaped by establishment of ECSC in coal and EURATOM in nuclear energy. Later, by Treaty of Rome signed in 1957, the responsibility of oil, natural gas, and electricity were given to EEC. During 1970's, the energy had a more important place in the agenda of EU as a result of oil crisis and as a part of the Single Market objective, energy was inserted into the priority issues of European Union. In the forthcoming years, the thought that single market was necessary for energy and steps towards this objective were taken. The most important of these steps is taking the decision of making attempts towards establishment of common policies in many fields, including energy, by Maastricht Treaty. However, in the beginning of 2000's, it is not possible to say a common energy policy is established, yet. Accordingly, 2009 Lisbon Treaty is a milestone in this context. Because the energy subject was included in the treaty text for the first time with Lisbon Treaty, therefore, energy has gained a different dimension and legal grounds.

In the current situation, despite specified energy regulations in European levels, there are 28 national regulatory structures in practice. With the using energy production facilities more effectively in EU general, a need for an integrated energy market is present for increasing market effectiveness and competition, to provide production in suitable prices for consumers and to act as a whole. Accordingly, the thought of forming the Energy Union was developed and European Commission has published its detailed action plan on Energy Union on 25th February 2015. Energy Union is designed for reinforcing the energy supply security, sustainability, and competition.

The purpose of this study is to examine the historical process of attempts on forming a common energy policy in EU and to discuss the future of Energy Union.

\section{Historical Process of Forming a Common Energy Policy in the EU}

To grasp the current situation of EU energy policy, one must look into how it is shaped throughout the history.

\section{Attempts Made in the Period Through Date of Establishment to Days of Oil Crisis}

Dating back to 1950's, the EU energy policy was started to take shape by Paris Treaty, which was signed for 50 years and found ECSC in 1951. With ECSC, coal and iron-steel industries were subjected to provisions of Paris Treaty. ESCS, aiming establishment of free and integrated markets in the mentioned industries, targeted removing the obstacles before the trading between member states and establishment of a common market by controlling subsidies and grants given by states, measures, and applications discriminating in especially price or delivery terms or shipping tariffs, between manufacturers, buyers, or consumers and amount restrictions in circulation of goods (State Planning Organization, 1993).

Established in 1957 by Treaty of Rome, EURATOM coordinates the research programs planned or carried out by member states for peaceful use of nuclear energy. In the Article 4 of the Treaty, it is emphasized that the Commission is obligated to develop and facilitate the nuclear research in member states to promote development in nuclear energy field and to complete these researches by means of putting research and training programs of the Community into practice. Also, the Treaty aims for the construction of essential facilities necessary for development of nuclear energy within the Community (State Planning Organization, 1993). 
However, the decisions taken and policies applied regarding nuclear energy are determined by national governments. Therefore, EURATOM does not contribute to establishment of a common energy policy.

Found in 1957 by Treaty of Rome, EEC proposes establishment of a system to ensure the forming of a common policy and prevent competition failure in a common market in industries such as agriculture and transportation (Treaty of Rome, Article 3). Operation of crude oil, natural gas, and electric industries is left to market conditions regulated by general provisions of Treaty of Rome, but no provisions regarding energy policy were directly given place in the treaty text which found EEC (Ege, 2004).

Neither ECSC, nor EURATOM and EEC could contribute to the establishment of a common energy policy. Therefore, steps were taken towards establishment of a common market for energy at the beginning of 1960's. In 1962, a memorandum which specifies extensive common policy objectives and applicable methods on energy policy was prepared. These objectives set forth the long-term goals and transition rules to facilitate the gradual compliance of national policies. European Parliament has set forth the essential principles for establishment of a common energy policy as decreasing expenses, energy supply security, coordination between energy policies of member states, long-term supply stability, freedom of choice for consumers, and establishing a common market for energy products. Also, three periods were proposed in memorandum of understanding. The end of preparation period was specified as 1st January 1964, transition period as between 1st January 1964 and 1st January 1970 and the beginning of the last period as 1st January 1970 (European Commission, 1963).

Following the energy policy memorandum, the Commission has concentrated on developing a common policy in energy field in 1968 and published the first guideline for establishment of a common market for the Community. The reason for establishing such an energy market was the presence of serious commercial obstacles for energy products unlike other industrial and agricultural products. If this wasn't fixed and a common energy market was not formed in the near future, the integration level obtained in this field would be in danger. Due to each member state having different energy policies, the differences between energy use costs were increasingly deteriorating the competition in the industries consuming high amounts of energy and hurting some regions of the Community more than others when important investment decisions are taken. An idea was set forth that this situation can only be fixed by establishment of a common energy policy in Community level and the Commission has included the essential principles specified by European Parliament in priority objectives in 1962 (European Commission, 1968).

However, the desired common market objective could not be attained since the day it was established until 1970's and following the 1973 oil crisis, works were sped up to establish a more stable energy policy.

\section{Oil Crises and Attempts Made in the Period Until 2009 Lisbon Treaty}

In 1970, EU was supplying about 53\% of its energy requirement from imported resources (World Bank, 2015). This dependence on foreign sources has left EU in a difficult situation against supply shortages and price increases arriving with the two oil crises of 1973 and 1979. Therefore, the two oil crises which happened in 1970s caused the energy to hold an importance place in agenda of European Union and as a part of the Single Market objective, energy was included in the priority objectives of European Union. In this context, as a result of the oil crises happened, "New Energy Policy Strategy" was accepted by European Commission in 1974 and a strategy was specified for the first time in EU energy policy (Yorkan, 2009). The new energy policy strategy had two main objectives as the supply and demand aspects of energy. The objective determined in terms of 
energy demand was the decreasing of energy consumption by efficient use of energy without endangering the social and economic growth objectives. The objective determined in terms of energy supply, meanwhile, was increasing production of nuclear energy and establishment of energy supply security by diversification of source countries in importation (The European Council, 1975a). To attain these objectives, member states have started taking energy saving measures and conducting works to decrease the weight of oil in the energy composition and increase alternative energy sources (The European Council, 1975b). Also, to prevent the European Union from another oil shock, the minimum stock amount was increased from 65 days to 90 days (The European Council, 1974).

In 1980's, the opinion of single market being necessary for energy was started to become dominant among member states and this opinion has started to become prominent especially with 1987 Europe Single Paper and the following Single Market objective. One of the most important changes brought by Europe Single Paper is the addition of a provision on the necessity of taking measures regarding gradual establishment of domestic market $^{1}$ in Treaty text that formed EEC (Europe Single Paper, Article 13). Also, Environment Subject (Subject VII) and an article concerning careful and rational use of natural sources to the third section of EEC Treaty by Europe Single Paper (Ministry of Finance, General Directorate of Budget and Fiscal Control, 2007).

One of the works carried out towards establishing a common policy in 1990's is the Maastricht Treaty (European Union Treaty) which entered into effect in 1993. Maastricht Treaty is considered as the most extensive regulation put into effect after Treaty of Rome and decisions were taken for attempts in establishment of common policies in many fields, including energy, however, no provision regarding energy policy was directly set forth in the Treaty text (TBMM, 2015).

In 2000's, meanwhile, it is not possible to say that a common energy policy is established, yet. However, the works on establishing a common energy policy in EU level continue. In 2006, the European Commission has published the Green Paper on European Strategy for Sustainable, Competitive and Safe Energy, which is also known as European Energy Strategy. It focuses on establishment of EU energy policy in three objectives as sustainable, competitive, and safe. For realization of these objectives, it is emphasized that a completely competitive energy domestic market is required to be formed and the supply security and low prices can be ensured. Also, six priority fields as establishment of a competitive domestic market, ensuring energy diversification, acting together in case of a problem in energy supply security, sustainable development, and innovation in energy and Europe being a world leader in technology were determined (European Commission, 2006).

Three energy packages were published towards liberalization (establishment of energy domestic market) of electricity and natural gas markets in EU. Within scope of "First Energy Package", Electricity Directive was published in 1996 and Natural Gas Directive in 1998. Because the desired liberalization could not be attained in electricity and natural gas markets with these directives, new directives were published within scope of "Second Energy Package" in 2003.

Within scope of "Third Energy Package" issued upon non-establishment of the desired liberalization, three by-laws and two directives were put into effect in 2009. Within scope of the by-laws issued, ACER (Agency for the Cooperation of Energy), ENTSO-E (European Network of Transmission System Operators for

\footnotetext{
${ }^{1}$ Single European Act, Article 13: Domestic Market includes an area without inner borders, ensuring free circulation of products, people, services and capitals according to provisions of this Treaty.
} 
Electricity), and ENTSO-G (European Network of Transmission System Operators for Gas) commenced operations. Increase of interconnection between national electric networks is expected to increase energy supply security, decrease energy prices due to increased competition, and ensure decarbonisation by facilitating transport of various renewable energy sources (wind and solar) from producers to consumers. Also, the Electricity Directive 2009/72/EC and Natural Gas Directive 2009/73/EC were published. The Electricity Directive 2009/72/EC sets forth the common regulations on production, transmission, distribution, and supply of electricity by an outlook taking care of provisions regarding protection of consumer and integrating the competitive electricity markets within Community (The European Parliament and the Council, 2009a). The Natural Gas Directive 2009/73/EC, meanwhile, sets forth the common regulations on natural gas transmission, distribution, supply, and storage. These common regulations also include the LNG (The European Parliament and the Council, 2009b). Consequently, a well-functioning energy market requires an effective regulatory framework. The third energy package establishes the necessary units to ensure cooperation between transmission system operators and regulators.

\section{Lisbon Treaty and Energy Gaining a New Dimension}

EU founding treaties did not contain special and individual articles for energy policy since the beginning; instead, EU institutions took advantage of relevant sections of treaties on environment and economy to put various principles and regulations on energy to effect (Eriş, 2012).

The Lisbon Treaty, coming into effect in 2009, has changed the name of the treaty ${ }^{2}$ that found European Community as Treaty on the Functioning of the European Union (TFEU). Energy subject was included in the Treaty text for the first time with 2009 Lisbon Treaty (Subject XXI) and the energy issue has attained a new dimension by energy subject being included in the Treaty text. Article 194 of the Treaty covers the objectives specified by considering the energy policy of the Union, within framework of establishment and operation of the domestic market and the need for protection and improvement of environment. Also, another innovation brought by the Treaty in energy field is inclusion of energy to the jurisdiction shared among Union and member states (TFEU, Article 4).

\section{Energy Union}

In the current situation, despite specified energy regulations in European levels, there are 28 national regulatory structures in practice. With the using energy production facilities more effectively in EU general, a need for an integrated energy market is present for increasing market effectiveness and competition, to provide production in suitable prices for consumers and to act as a whole. Accordingly, the thought of forming the Energy Union was developed and European Commission has published its detailed action plan on Energy Union on 25th February 2015. Energy Union is designed for reinforcing the energy supply security, sustainability, and competition (European Commission, 2015). The detailed action plan essentially focuses on research and innovation as well as energy supply security, completion of energy domestic market, energy efficiency, and decarbonization.

\section{Establishment Process}

In the process leading to Energy Union, the first step was taken by Poland Prime Minister Donald Tusk.

\footnotetext{
${ }^{2}$ With the Treaty of European Union, the name of the Treaty forming European Economic Community is changed as Treaty forming the European Union.
} 
The proposal of Tusk ${ }^{3}$ was forming an energy union with the focus of energy supply security and a domestic energy market. In May 2014, European Commission has set forth the European Energy Security Strategy regulating the short, middle, and long term key actions for finding solutions and talking as one voice, based on better coordination of national energy policies. In July 2014, the political principles of Jean-Claude Juncker include prospective climate change policy as one of the 10 priorities $^{4}$ of the Commission and Energy Union. In November 2014, President of the Commission Juncker has assigned Maroš Šefčovič as Vice President of Energy Union. An Energy Union conference was organized in Riga, under the EU term presidency of Latvia on 6th February 2015 and the European Commission has published the action plan on Energy Union on 25th February 2015 (The European Parliament, 2015).

The strategy of Energy Union in 2014 sets forth an integrated approach targeting coordination and integration of EU and member states' energy policies beyond the proposal of Donald Tusk, which only focuses on supply security. The application of the strategy requires addition of new articles to EU legislation applicable by European Parliament and Council under ordinary legislative procedure.

\section{Reasons of Establishment for Energy Union}

Energy Union, essentially, pursues the goal of forming a structure where it is possible to talk with one voice in global market, establishes an integrated energy system which competition and sources are used as well as possible and circulate among countries freely, energy markets in EU level subjected to an effective regulation, sustainable, low carbon, and environment friendly economy; presence of strong, innovative, and competition based European companies, has a labor market which has the ability to establish and manage the energy system of the future and making use of new technologies to reduce the bills, participate actively in the market where defenseless customers can be protected (European Commission, 2015).

\section{Focus Points}

Energy Union Strategy gathers around five dimensions (Table 1) (European Commission, 2015).

Table 1

Five Dimensions of Energy Union Strategy

\begin{tabular}{|l|l|l|l|l|}
\hline st dimension & 2nd dimension & 3rd dimension & 4th dimension & 5th dimension \\
\hline $\begin{array}{l}\text { Energy supply security } \\
\text { Solidarity } \\
\text { Trust }\end{array}$ & $\begin{array}{l}\text { A completely integrated } \\
\text { European energy market }\end{array}$ & Energy efficiency & Decarbonization & $\begin{array}{l}\text { R\&D } \\
\text { Innovation } \\
\text { Competition }\end{array}$ \\
\hline
\end{tabular}

The first dimension, which is solidarity and trust based energy supply security, focuses on supply sources, diversification of suppliers and energy lines, member states acting in a tighter cooperation, a stronger Europe in global energy markets and increasing transparency in gas supply contracts.

The second dimension, which is a completely integrated Europe energy market, aims to complete domestic energy market, complete implementation of the third energy package, reinforcing regulatory framework and improving transfrontier networks by establishing an EU-wide energy retail market.

With the energy efficiency dimension, it aimed to secure energy supply security by lowering energy

\footnotetext{
${ }^{3}$ Prime Minister of Poland, Donald Tusk has pointed out in 2014 that for the European energy markets to be freed of Russian dependency, an Energy Union must be established.

4 Ten priority: Status of the Union; Work, Growth and Investment; Digital Single Market; Energy Union and Climate; Domestic Market; Economic and Monetary Union; EU-USA Free Trade; Justice and Basic Rights; Immigration; EU as Global Actor; Democratic Change (http://ec.europa.eu/priorities/index_en.htm).
} 
demand. Transportation and construction industries are shown as targets in industries with great potential for energy efficiency measures. Also, it is expressed that member states should prioritize energy efficiency in their energy policies.

The fourth dimension is the decarbonization which goes hand in hand with climate policy of EU. Commission sees the EU as a global hub for development of new generation renewable energies. Accordingly, the Commission aims to make EU a world leader in this industry by preparation of markets for the increasing share of renewable energies and increasing investments to improved sustainable, alternative fuels.

The fifth and last dimension, $R \& D$, innovation, and competition, meanwhile, focuses on renewable energy and energy storage, smart networks, participation of consumer, buildings consuming energy as much as they produce, efficiency of energy systems, and sustainable transport systems. The research priorities are, accordingly, carbon capture and storage and nuclear energy for those member states which want to utilize them.

\section{Energy Union in 15 Points of Action Plan}

For the establishment of Energy Union, a 15 Points Action Plan seen as essential priorities by the Commission was set forth (Gurzu, 2015):

(1) Full implementation of current energy legislation

(2) Establishment of a new legislation on electric energy supply security in 2016

(3) Reviewing of natural gas supply directive, an extensive LNG strategy, approaching new gas suppliers

(4) Full compliance of intergovernmental treaties with EU laws

(5) Providing support for large infrastructure projects with current financial capacity of EU

(6) Establishing of a new electric market design in 2015 to combat unplanned development of capacity mechanisms

(7) Reinforcing the EU regulatory framework by providing more authority to ACER and ENTSO G/E

(8) Improving regional cooperation approaches

(9) Preparing biennial reports in energy prices

(10) Reviewing energy efficiency legislation in 2015 and 2016

(11) Developing the strategy to facilitate investments in heating and cooling industry and "Smart Financing for Smart Buildings" initiative for energy efficiency

(12) Preparing an extensive road transport package focusing on infrastructure pricing, energy efficiency, and development of alternative fuels

(13) Proposing a new legislation to attain the 2030 reducing greenhouse gas objective in both ETS $^{5}$ and non-ETS industries

(14) Establishing a new renewable energy package for the year 2016-2017

(15) Contribution to economic growth and employment by developing energy and climate based on technology and innovation approaches

In establishment of Energy Union, the Commission thinks of utilizing all current policy instruments to ensure the member states completely implement the energy legislation especially in the Third Energy Package. One of the priority objectives in the policies specified by the EU is energy supply security. Therefore, it has to diversify the gas supply. In the process of establishing Energy Union, the Commission sets forth the objectives of reviewing natural gas supply legislation, an extensive LNG strategy and approaching new gas suppliers.

\footnotetext{
5 Emission Trade System.
} 
EU thinks that for establishment of Energy Union, legislation should be reinforced, current legislation should be revised, and these legislations should be in compliance with EU laws, therefore prioritizes these in the specified action plan. Accordingly, in the specified action plan, establishment of the new legislation regarding electric energy supply security in 2016, reviewing all related energy efficiency legislation in 2015 and 2016 to attain minimum 27\% energy saving specified until 2030 and proposing a new legislation to attain the objective of 2030 greenhouse gas reduction in both ETS and non-ETS industries specified by European Council in 2014. Also, the revision of intergovernmental treaties for the purpose of compliance with EU legislation is proposed by including the Commission in treaty negotiations for improving treaty provisions covering EU regulations and making gas supply agreements more transparent.

Ensuring energy efficiency is among the objectives set forth in EU level and 2020 and 2030 objectives are one of the indicators of this. Therefore, energy efficiency is given place in the action plan specified for the establishment of Energy Union. Accordingly, the objective of developing strategy to facilitate "Smart Financing for Smart Buildings" initiative and investments in heating and cooling industries and thus decreasing energy importation bill of EU, contributing to ensuring energy security and reducing energy costs for residences and businesses are aimed. Besides, reaching minimum $27 \%$ in utilizing renewable energy resources by 2030 is required; accordingly, the objective of forming a renewable energy package for the year 2016-2017 is set forth.

\section{Management of Energy Union}

Energy Union requires an integrated management and monitoring process to be informed of actions related to energy in regional, national, and local level to contribute to the objectives of Energy Union.

The management process, meanwhile, pursues a goal of actions in other policy fields to ensure consistency of a longer term policy as well as gathering energy and climate actions together, securing implementation of 2030 objectives on energy and climate and domestic energy market, regulating the current planning and reporting requirements by avoiding unnecessary management load, forming an energy dialogue with shareholders to inform about policy creation processes, supporting active participation in energy transition management, deepening the cooperation between member states and the Commission, developing the data, analysis, and intelligence required for Energy Union, and submitting annual reports to European Parliament and Council regarding the status of Energy Union (European Commission, 2015).

\section{Conclusions}

Cooperation in energy field was in the center of European integration from the beginning by establishment of European Coal and Steel Community in 1952 and European Nuclear Energy Community in 1957. The domestic market for electricity and natural gas in European Union was tried to be established by three liberalization packages (energy packages) which were accepted in 1990, 2003, and 2009. However, upon incomplete realization of desired liberalization, the last act set forth by the Commission to form an integrated energy market is forming of Energy Union.

Energy strategy in EU is based on the objectives of ensuring operation of energy market between member states by the spirit of solidarity, ensuring energy supply security in the Union, supporting of energy efficiency, energy saving, and new and renewable energy sources improvement, and supporting of interconnection of energy networks. To attain these objectives, an integrated, competitive, and sustainable single energy market is 
required to be established. However, reasons such as an integrated energy market still not established, excessive dependency to a single supplier (approximately 33\% dependency rate to Russia), and 53\% of the energy utilized consisting of imported sources constitute an obstacle in attaining these objectives. Therefore, to overcome these obstacles and talk as one voice, it is thought that Energy Union should be formed and a detailed action plan was published by the Commission in February 2015.

Since European Coal and Steel Community, Energy Union is considered as the most ambitious energy project in Europe. However, Energy Union is not a new concept suggested. The objectives set forth in Energy Union action plan include the measures to be taken for necessary legal regulations, market operation, and removing these faults. In short, Energy Union aims for the integrated realization of the pre-existing objectives.

Energy Union should not be seen as a project that can be put into practice in short term. Because the energy issue is not something that member states want to transfer their power. For establishment of Energy Union, a consensus must be established between member states for conformity of EU energy policies. Therefore, it is expected for the establishment of Energy Union in long term.

\section{References}

Ege, A. Y. (2004). Avrupa Birliği'nin Enerji Politikasi ve Türkiye'nin Uyumu. Ulusal Politika Araştirmalari Vakfi, Avrupa Birliği'nin Enerji Politikasi ve Türkiye. Europa Bilgi Köprüleri Programi.

Eriş, Ö. Ü. (2012). Enerji Politikasi. In B. Akçay and İ. Göçmen (Eds.), Avrupa birliği: Tarihçe, teoriler, kurumlar ve politikalar Ankara: Seçkin.

European Commission. (1963). Energy policy in the European Community, Community Topics 9. Retrieved from http://aei.pitt.edu/view/year/1963.html

European Commission. (1968). First Guidelines for a Community Energy Policy, COM (68) 1040, No. 12, Brussels.

European Commission. (2006). Green Paper on a European Strategy for Sustainable, Competitive, and Secure Energy, COM (2006) 105 final, Brussels.

European Commission. (2014). Communication from the Commission to the European Parliament and the Council, COM (2014) 330 final, Brussels.

European Commission. (2015). Energy Union Package, COM (2015) 80 final, Brussels.

Gurzu, A. (2015). Fifteen steps to build Energy Union: Leaked document. Europolitics, No. 5035.

Ministry of Finance, General Directorate of Budget and Fiscal Control. (2007). Single European Act. İktisadi Kalkınma Vakfi.

State Planning Organization. (1993). Treaty Establishing the European Community (ECSC, EEC, EURATOM). Ankara.

TBMM. (2015). Treaty on European Union, TBMM Kütüphanesi, 92/C 191/01. Retrieved from http://www.tbmm.gov.tr/kutuphane/AB/The_Maastricht_Treaty.pdf

The European Council. (1974). Opinion on the Proposal for a Council Directive Obliging the Member States of the EEC to Maintain Minimum Stocks of Fuels, 35.

The European Council. (1975a). Council Resolution of 17 September 1974 Concerning a New Energy Policy Strategy for the Community, 153(1).

The European Council, (1975b). Council Resolution of 26 June 1975 on the Setting of a Short-Term Target for the Reduction of Oil Consumption, 153(9).

The European Parliament and the Council. (2009a). Directive 2009/72/EC concerning common rules for the internal market in electricity and repealing directive 2003/54/EC. Official Journal of the European Union, L 211.

The European Parliament and the Council. (2009b). Directive 2009/73/EC concerning common rules for the internal market in natural gas and repealing directive 2003/55/EC. Official Journal of the European Union, L 211.

The European Parliament. (2015). Energy Union, new impetus for coordination and integration of energy policies in the EU. European Parliamentary Research Service, PE 551.310.

Yorkan, A. (2009). Avrupa Birliği'nin enerji politikasi ve Türkiye’ye etkileri. Bilge Strateji, 1(1), 24-39.

World Bank. (2015). World development indicators. Retrieved from http://databank.worldbank.org/data//reports.aspx?source=2\&Topic=5 